\title{
A TWO PHASE TREATMENT OF AN INFECTED HIP ENDOPROSTHESIS
}

\section{Jasmin Ciriviri ${ }^{1}$, Darko Talevski ${ }^{1}$, Zoran Nestorovski ${ }^{1}$, Tode Vraniskoski ${ }^{1}$, Snežana Mishevska-Perchinkova}

${ }^{1}$ City General Hospital „, $8^{\text {th }}$ of September“ - Skopje, R. Macedonia

${ }^{2}$ University Clinic for Rheumatology - Skopje, R. Macedonia

Coresponding Author: Jasmin Ciriviri, MD, City General Hospital „, $8^{\text {th }}$ of September“ - Skopje, Department of Orthopedics and Traumatology, Pariska Str. b.b. Skopje, Republic of Macedonia; Phone number: 02308 75 64;

E-mail: jasminc@unet.com.mk

\begin{abstract}
The revision of the two phase treatment represents a golden standard in the treatment of infected endoprosthesis. Throughout this study, the results of 21 patients with an infected hip endoprosthesis treated in two phases have been processed, with the use of an antibiotic spacer, within the period of 2009 and 2012.

Thereby, a unique protocol for diagnosis and treatment of infections has been applied to all the patients, which entails a preoperational x-ray image, laboratory findings (Se, CRP), as well as a puncture aspiration with a microbiological and biochemical examination of the aspirated fragments. The operational treatment consists of: taking a sample for microbiological and histopathological diagnosis, removal of the implanted endoprosthesis, excision of the avascular and necrotic tissue and installing an antibiotic spacer. Postoperatively, the patients are treated with a parenteral application of an antibiotics based on an antibiogram, throughout a period of two weeks, and later on an oral treatment, a combination of two antibiotics, depending on the antibiogram, within the following four to six weeks. After the appeasement of the local findings and the laboratory results, a revision with a removal of the antibiotic spacer and reimplantation of an endoprosthesis - revisional or primary has been conducted on the patients, depending on the bone deficit. The functionality of the joint is graded based on the Haris Hip Score. The patients are being observed postoperatively for a period of 12 to 36 months.

A definite reimplantation has been applied to 20 patients, while one patient has been treated with a resection method. The Haris Hip Score was 45 preoperatively, and 80 postoperatively.

The applied protocol of the treatment of infected endoprosthesis is effective in the eradication of the infection and the final reimplantation.
\end{abstract}

Key words: infection, hip, endoprosthesis, spacer

\section{Introduction}

The periprosthetic infections are classified in four basic categories:

- Type I - early postoperative,

- Type II - late chronic,

- Type III - acute hematogenous and

- Type IV - positive intraoperative culture (Segawa et al [1]).

A certain sign for diagnosing a periprosthetic infection is:
1. Having a draining sinus which communicates with the prosthesis,

2. An isolated bacteria of at least two distinct tissues or liquid from the affected joint.

3. If 4 out of the 6 criteria are present:

- Accelerated sedimentation and an increased value of CRP (C-reactive protein);

- Increased leukocyte count in the aspirational fragment; 
- Dominant presence of neutrophils in the aspirated fragment,

- Pus presence in the joint,

- Isolated bacteria from an aspirated fragment, and

- Presence of more than 5 leukocytes during a microscopic check of the aspirated fragment.

The deep periprosthetic infections in the endoprosthetic surgery represent a serious problem and their treatment requires additional material means. Meanwhile, a few optional treatments are possible:

1. Long term antibiotics treatment [2],

2. Girdlestone resection [3, 4],

3. Debridement with keeping the prosthesis [5],

4. One act revision [6],

5. Two phase revision, with a setup of an antibiotic spacer [7].

It is generally accepted notion that it is impossible to calm the infection without removing the implants, however, the endoprosthesis resection, even when it is applied as a temporary method, is accompanied with a significant loss of its function.

The one act revision has an advantage of keeping the function of the extremity, without a time lapse, it shortens the duration of the treatment, as well as the expenses, however, it is indicated in patients who fulfill certain prerequisites, such as general wellbeing, inexistence of a draining sinus, little bone deficit, good local findings, a known bacterial cause, and a mandatory use of a cement prosthesis with an impregnated antibiotics in the bone cement [8].

A renowned standard in the treatment of the late chronic infection is the two phase treatment, which includes a removal of the implanted prosthesis, a debridement of the surrounding tissue, setting up an antibiotic impregnated spacer, an intravenous application of an antibiotic and a postponed revision arthroplasty. The antibiotic spacer represents a solid base for local release of large amounts of antibiotics, which prevent the retraction of the surrounding muscular tissue and enable certain movements of the hip, due to which it represents an acceptable alternative to the removed prosthesis during the treatment of the infection [9]. The spacers can either be factory-made and through an order form to contain added antibiotics or can be made in the operating room, using special molds and manually added antibiotics [10].

Rooting out the infection has a higher success rate with the two phase revisions, rather than the one phase revision. The two phase revision represents a standard procedure in our facility, not only because of the higher percentage of eradication of the cause, but also because of the increased percentage of resistant bacteria. The two phase revision consists of two procedures, and those are: 1. Removal of the infected prosthesis along with removal of the devitalized tissue, and 2. Implantation of an appropriate cement spacer. After 8-12 weeks, a period during which the patient is treated with a systemic antibiotic treatment, the second phase follows after the serological markers of the infection have been normalized, which consists of 1 . Removal of the antibiotic spacer and a repeated debridement of the devitalized tissue, and 2 . Significant rinsing and reimplantation of the hip endoprosthesis, which, depending on the bone deficit, is primary or revisional. The function of the spacer during the time between the removal of the prosthesis and its reimplantation is repeated, with the purpose of decreasing the adhesions between the tissues, enabling movement in the joint, maintaining contractility and length of the musculature, and most importantly, releasing large amounts of antibiotics - locally in the infected area. The purpose of this study is to estimate the effectiveness of the two phase revision with the use of an antibiotic spacer with the method of treatment according to the protocol that is being followed in our facility.

\section{Matherials and methods}

Twenty one patients are included in the study with an infected hip endoprosthesis, out of which 13 are women and 8 are men. The average age during the first intervention of the treated patients was 59 years (28-79).

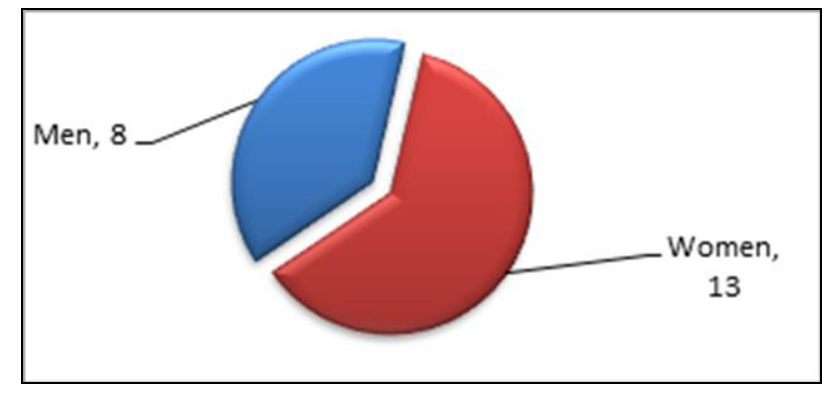

Graph 1-Gender of the patients 


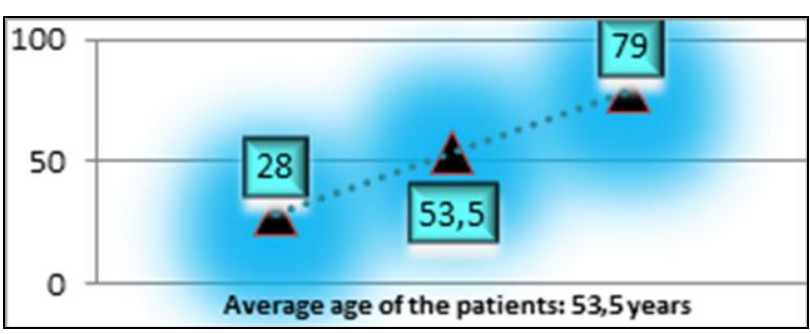

Graph 2 - Youngest, oldest and average age

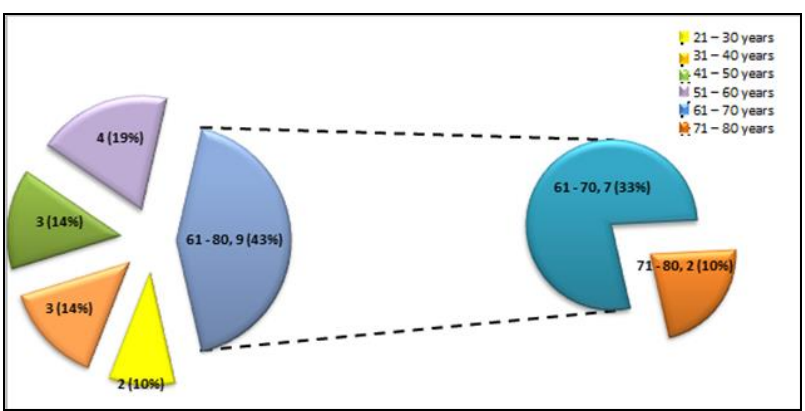

Graph 3 - Age according to age groups and $\%$ of participation

The infections are being diagnosed with a clinical exam, x-ray examination, laboratory examinations (Se, CRP), and aspirational punctuation of the hip. In patients with fistula, the aspirational punctuation of the hip was not performed. Moreover, it is important to mention that the presence of fistula represents a certain sign of infection.

The preoperational clinical examination includes: general wellbeing, pain, and local status. The preoperational $\mathrm{x}$-ray examinations included: $x$-ray of the pelvis with the hips and an x-ray of the hip with the thigh. A lateral approach has been used in the surgical treatment.

In the first surgical phase the hip endoprosthesis is removed with a careful and precise approach to the bone tissue, synovectomy and debridement of the devitalized tissue. Three swab samples have been taken for microbiological testing from the joint capsule, acetabulum and femoral channel, as well as material for histopathological evaluation. A substantial irrigation and lavage has been applied in the operational area, and then an antibiotic spacer is set up.

The antibiotic spacer that is being used in these procedures is a non-serial personal product, made in a mold in which 40 gr. antibiotic gentamycin bone cement has been inserted with addition 4 gr. of Vancomycin or another antibiotic (Meropenem), depending on the sensitivity of the isolated cause towards antibiotics.
In the bone cement, for greater firmness, one 5 $\mathrm{mm}$. metal pin has been inserted. At the end of the surgical intervention, a vacuum drainage system has been set up, for the duration of the initial 24 hours. Postoperatively, during the next two weeks, the patients have been treated with an intravenously applied antibiotic, and in the duration of the next four weeks with per os treatment. The antibiotic therapy is ordinated depending on the antibiogram. The patients are being verticalized during the first postoperative day, after the removal of the drainage, during which the burdening of the operated extremity is touching the floor. The control x-ray image is made the first postoperative day, blood analysis following protocol the first two days, and Se and CRP one month after the first intervention. After the tranquilizing of the SE and CRP, 2-3 months after the first intervention, a second surgical intervention is conducted, by removing the antibiotic spacer and reimplantation of the hip endoprosthesis (primary or revisional, depending on the bone loss). During the second surgical intervention three samples for microbiological culture have been taken again, as well as two samples for histopathological diagnosis. Once again, a debridement has been conducted at the leftover or the newly devitalized tissue. The antibiotic treatment has been prolonged until the results from microbiological analysis have been completed. If the microbiological results were positive, the antibiotic treatment was prolonged for 6 weeks. If the microbiological results were negative, the patient was only observed during the following period, without an antibiotic treatment. If, after the six week period after the first intervention, the laboratory analysis were still not tranquilized or a fistula was present, in that case the second surgical intervention consisted of a change in the spacer and a debridement. The patients are continually followed, clinically, radiographically and with the Haris Hip Score [11], which is measured before the first intervention and one month after the second intervention, as well as during each of the following follow-ups, more specifically after $3,6,12,18$, and 24 months. The incorporation of the allograft was investigated with a comparison of the $\mathrm{x}$-ray examinations. 


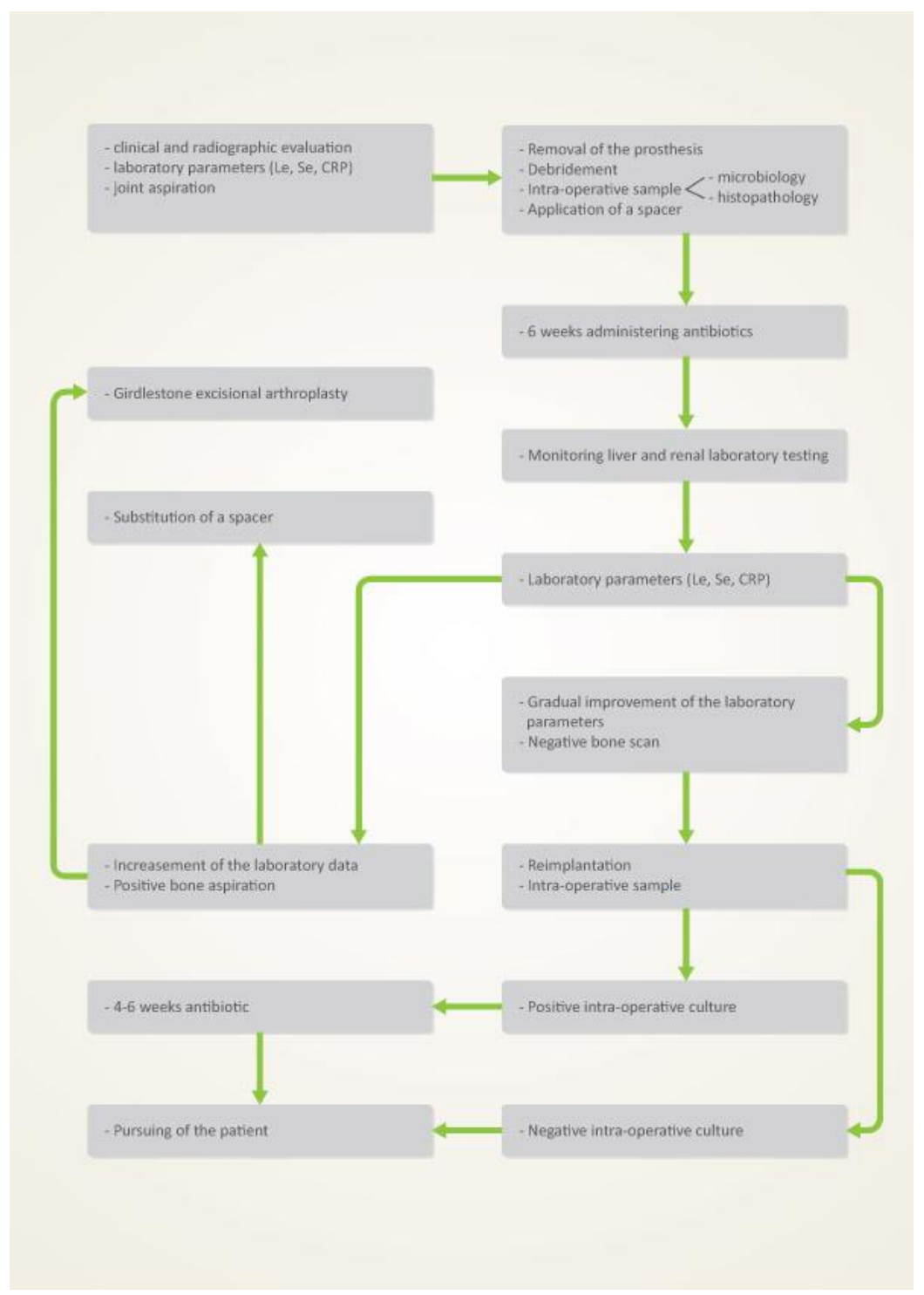

Image 1 -A protocol for diagnosis and treatment for the hip infected endoprosthesis

\section{Results}

In the presented study, the protocol for diagnosis and treatment for an infected hip endoprosthesis has been applied.

\section{Preoperative evaluation:}

Pain is the main symptom in all patients. CRP and/or SE have increased at all patients prior to the surgery. Three patients had a drainage sinus. Radiographically, one patient experienced a loosening of the acetabular component, three patients experienced osteolysis surrounding the acetabular component, and two experienced osteolysis surrounding the femoral component. There were no significant changes on the x-ray examinations in the other patients.
The median time since the implantation of the prosthesis until the appearance of the symptoms was 16 months (1.5-23). According to Tsukayama [12] classification, a late chronic infection had been diagnosed in all the patients. A swab sample had been taken from the wound of the patients with a drainage sinus, however, at only two out of three observed patients, a microorganism had been isolated. An aspirational puncture was performed on the other 18 patients, and the aspirated fragments were microbiologically and biochemically examined. A bacterial cause was isolated in 14 of them. An increased number of leukocytes was found in 15 patients, and neutrophils dominated in all of them. 
First surgical intervention and the period after it:

A manually made antibiotic spacer was set up in all the patients, in which two antibiotics were inserted: Gentamycin, which is placed in the cement during the production process in the factory, and Vancomycin added by us, 4 gr. (at 16 patients) or Meropenem (at 5 patients), depending on the isolated bacterial cause during the aspirated tracer of the hip.

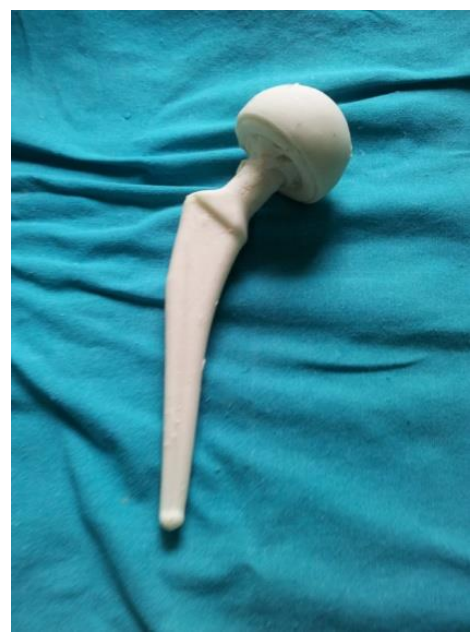

Image 2 - A manually made antibiotic spacer

Isolated causes for infection are:

- Staphylococcus epidermidis (in 6 patients),

- Staphylococcus aureus (6),

- Enterococcus (4),

- Esherichia colli (2),

- Klebsiela pneumoniae(1) and

- Proteus (1), while

- No isolated cause has been found in one patient.

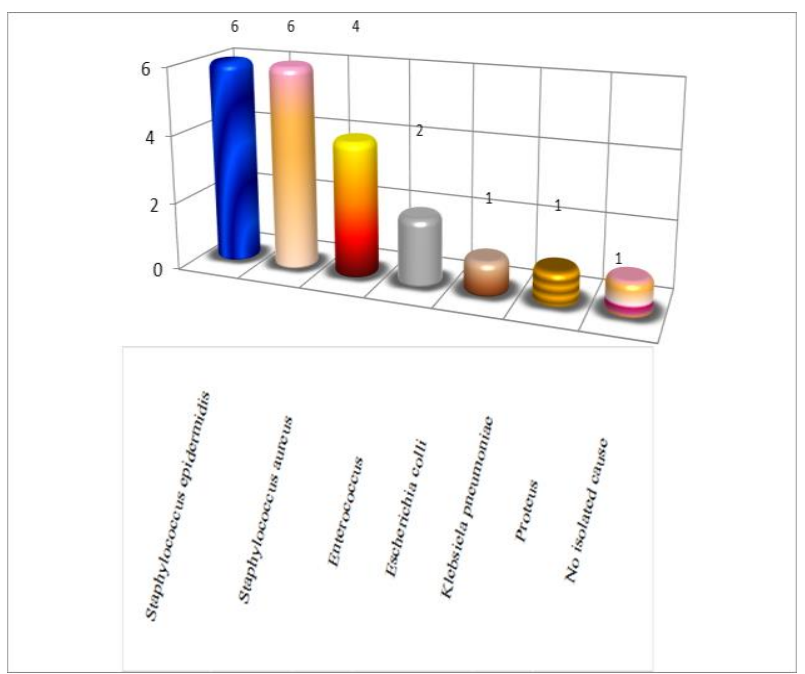

Graph 4 - Isolated bacterial causes for infections
In one patient (Staphylococcus aureus) the eradication of the infection was not accomplished with this method, and because of that the hip resection arthroplasty was applied (Girdlestone method [13]).

\section{Second surgical intervention:}

Twenty patients, except for one where a resection arthroplasty has been applied, were surgically treated with a revisional hip arthroplasty, during which 20 non-cement acetabular caps (9 revisional) were used, 16 non-cement stems (12 revisional) and 4 cement revisional stems. A bone allograft was used on 14 patients, for the purpose of filling an acetabular defect.

\section{Table 1}

Used endoprosthetic material

\begin{tabular}{|c|c|c|}
\hline \multicolumn{3}{|c|}{ Acetabular caps: } \\
\hline & - Non-cement: & 20 \\
\hline & primary & 11 \\
\hline & revisional & 9 \\
\hline & & \\
\hline \multicolumn{3}{|c|}{ Femoral stems: } \\
\hline & - Non-cement: & 16 \\
\hline & primary & 4 \\
\hline & revisional & 12 \\
\hline & - Cement: & 4 \\
\hline & revisional & 4 \\
\hline
\end{tabular}

The results of the microbiological and histopathological intraoperative examinations demonstrated a presence of a bacterial cause in one patient (one positive swab sample of Staphylococcus aureus of three taken) and as a result, this patient was treated with antibiotics during the following 6 weeks.

Postoperatively, the patients were a subject to clinical, laboratory, and x-ray examination. After an average of 3 years (46-24 months), a reoccurrence of the infection has not been noted. The average postoperative Haris Hip Score is 80 .

\section{Complications:}

In the period between the two surgical interventions, three dislocations of the spacer and two fractures on the antibiotic spacer have happened. The complication after the second intervention, i.e., reimplantation of an endopro- 
sthesis, is a dislocation of a hip in two patients. Thus, an upsurge of the retroversion of the proximal part of the stem was done in one of the patients, and a revision of the acetabular component was done in the other patient.

\section{Radiographic examinations:}

Up until the last examinations, all the acetabular and femoral components have been radiographically stable, without signs of ostolysis and loosening. Also the bone allografts were incorporated.

\section{Discussion}

Currently, the two phase treatment of infected hip endoprosthesis represents a golden surgical standard around the world, despite the fact that it requires two surgical interventions, it represents a long and costly process, with a long duration of the healing, and a painful treatment and experience for the patient.

Generally, diagnosing a periprosthetic infection is a challenging problem to solve, because there is not a definite specific test that would help the diagnosing process. Because of this, after the completed reimplantation, the surgeon should face with circumstances whereas there are no certain signs of rooting out of the infection.

In this study, all the patients were treated following the same protocol, in two phases. The results of this study are, to a significant extent, compatible with those obtained from the consulted expert literature and the studies that elaborate problems from this range.

The periprosthetic infections caused by resistant bacteria compared to those caused by a nonresistant bacteria treated in two phases have an equal success rate. This is because of the application of antibiotics the bacteria is sensitive to, as well as the radical removal of the devitalized and necrotic tissue, also in two phases. Non-cement acetabular components were implanted in the second phase, and in the period between the postoperative time and the present, no radiological or clinical signs of loosening or osteolysis of the surrounding bone tissue have been noted.

In comparison to the non-cement femoral stems, there is no difference in the stability of the cement stems throughout this period. An an- tibiotic cement has been used at the cement prosthesis. The indications for using cement stems were the quality of the surrounding bone as well as the possibility for solid fixation of the femoral stem.

The bone allografts that are being used on the patients are of various sizes, depending on the bone defect of the acetabular walls, whereas all have been incorporated in the surrounding bone.

The complications that arose because of the application of the antibiotic spacer represent two types of dislocation, which are 1) dislocation due to an instability of the spacer in the femoral channel and the possibility of its rotation, in which case, for the purpose of avoiding this a fixation of the spacer with a small quantity of additional cement in the proximal part of the femur is recommended, and 2) dislocation which is caused by an acetabular deficit, whereas, unfortunately, there is no appropriate solution.

Another kind of complication is breaking of the spacer, which, occurred in two patients because of an inadequate and excessive burdening, despite the strengthening of the spacer with a metal pin.

Moreover, the firmness of the antibiotic spacer is a question to be discussed, which, due to the additional application of 4 gr. of antibiotics in $40 \mathrm{gr}$. of cement that is always applied in a combination with the factory-made gentamycin, decreases even more [14]. Still, hip movements are enabled, reduced in extreme amplitudes during burdening of about $50 \%$ of the body weight, with the help of two crutches.

The presence of the spacer prevents an occurrence of fibrosis in enormous quantities in the empty space of the hip, enables a moderate elasticity, tonus and trophy of the surrounding musculature [15]. The laboratory examinations concerning the added doses of an antibiotic do not demonstrate an intoxication of the liver or kidneys. An allergic reaction to the used antibiotics in the spacer has not been noticed in the patients either.

\section{Conclusion}

The results of this study during the period of observation of 12-36 months, show that with a continual following of the protocol for diagnosis and two phase treatment of an infected 
endoprosthesis of a hip, an eradication of the infection is accomplished with a high percent of efficacy of around 95,2\%.

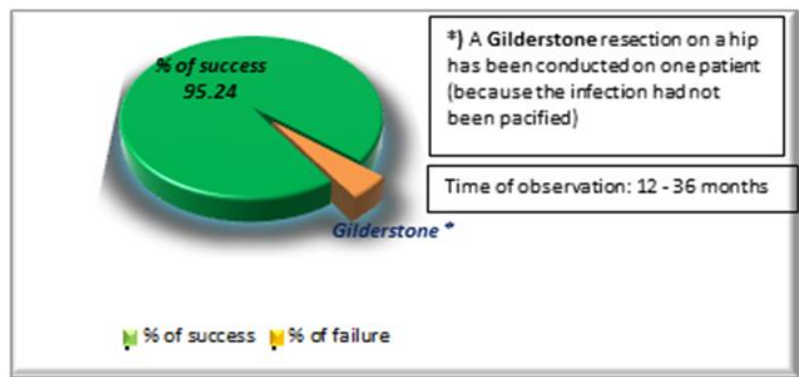

Graph 5-Rate of success

The antibiotic spacer enables a local discharge of a large amount of antibiotics in the operated wound, without endangering the general wellbeing of the patient. The hip's movements during the workings of the spacer are limited, yet possible, i.e., the patient moves with the help of crutches while only partially burdening the affected leg, thus significantly maintaining the function of the extremity during the definite surgical intervention. The antibiotic spacer that has been applied forbids the occurrence of a fibrously weak vascular tissue with a possibility of an antibiotic contamination. Although the firmness of the antibiotic spacer by adding antibiotics significantly decreases, its stability is firmed with the insertion of a metal pin, which in turn enables a partial burdening of the extremity. The results accomplished from the treated patients so far, as well as the conducted examinations, correspond with the results of the practical experiences around the world listed in the available expert literature [16], which represents a strong (sufficient) argument that leads to a conclusion that the manually made antibiotic spacer, which is being used in our institution, represents an appropriate, efficient, and an economically justified material of choice in the treatment of periprosthetic infections.

\section{REFERENCES}

1. Segawa H,Tsukayama DT, Kyle RF, Becker DA, Gustilo RB. Infection after total knee arthroplasty: aretrospective study of the treatment of eighty-one infections.J Bone and Joint Surgery[Am]. 1999; 81A: $1434-45$.

2. Goulet JA, Pellicci PM, Brause BD, Salvati EM. Prolonged suppression of infection in total hip arthroplasty. J Arthroplasty. 1988; 3(2): 109-16.
3. Canner GC, Steinberg ME, Heppenstall RB, Balderston R. The infected hip after total hip arthroplasty. J Bone Joint Surg Am. 1984; 66: 1393-99.

4. McDonald DJ, Fitzgerald RH Jr, Ilstrup DM. Twostage reconstruction of a total hip arthroplasty because of infection. J Bone Joint Surg Am. 1989; 71: 828-34.

5. Tsukayama DT, Estrada R, Gustilo RB. Infection after total hiparthroplasty. A study of the treatment of one hundred and six infections. J Bone Joint Surg Am. 1996; 78-A(4): 512-23.

6. Garvin KL, Hanssen AD. Current concepts review. Infection after total hip arthroplasty. Past, present, future. J Bone Joint Surg Am. 1995; 7-A(7): 1576-88.

7. Jamsen E, Sheng P, Halonen P, Lehto, et al. Spacer prostheses intwo-stage revision of infected knee arthroplasty. Int Orthop. 2006; 30: 257-61.

8. Dohmae Y, Bechtold JE, Sherman RE, Puno RM, Gustilo RB. Reduction in cement-bone interface shear strength between primary and revision arthroplasty. Clin Orthop Relat Res. 1988; 236: 21420.

9. Durbhakula CM, Czajka J, Fuchs MD, Uhl RL. Antibiotic loadedarticulating cement spacer in the 2stageexchange of infected total knee arthroplasty. J Arthroplasty. 2004; 19: 768-74, 19768, 2004; [PubMed] [Cross Ref]

10. Haddad FS, Masri BA, Campbell D, Mc Graw RW, Bauchamp CP, Duncan CP. The PROSTALAC functional spacer in two stage revision for infected knee replacements. J Boneand Joint Surgery Br. 2000:82:807-12.82807 2000 [PubMed][Cross Ref]

11. Meani E, Romano CL, Crosby L, Hofmann G. Infection and local treatment in orthopaedic surgery. Berlin Heidelberg (GER): Springer-Verlag, 2007.

12. Segawa H, Tsukayama DT, Kyle RF, Becker DA, Gustilo RB. Infection after total knee arthroplasty: Aretrospective study of the treatment of eighty-one infections.J Bone and Joint Surgery[Am]. 1999; 81A: $1434-45$.

13. Bourne RB, Hunter GA, Rorabeck CH, Macnab JJ. A six-year follow-up of infected total hip replacements managed by Girdlestone's arthroplasty. J Bone Joint Surg Br. 1984; 66: 340-3.

14. Younger ASE, Duncan CP, Masri BA, McGraw RW. The outcome of two-stage arthroplasty using a custom-made interval spacer to treat the infected hip. J Arthroplasty. 1997; 12(6): 615-23.

15. Younger ASE, Duncan CP, Masri BA. Treatment of infection with segmental bone loss in the proximal part of the femur in two stages with use of antibioticloaded interval prosthesis. J Bone Joint Surg Am. 1998; 80-A(1): 60-9.

16. Giovanni Pignatti,Shingo Nitta, Nicola Rani, Dante Dallari, Giacomo Sabbioni, Cesare Stagni and Armando Giunti: Two Stage Hip Revision in Periprosthetic Infection: Results of 41 Cases. J Bone and Joint Surgery[Am]2010;4: 1874-3250/10 2010 Bentham Open. 193-200. 
Резиме

\section{ТРЕТМАН ВО ДВЕ ФАЗИ НА ИНФИЦИРАНИ ЕНДОПРОТЕЗИ НА КОЛК}

Јасмин Циривири ${ }^{1}$, Дарко Талевски ${ }^{1}$, Зоран Несторовски $^{1}$, Тоде Вранишкоски ${ }^{1}$, Снежана Мишевска-Перчинкова ${ }^{2}$

${ }^{1}$ ЈЗУ Градска општа болница „8 Септември“ Скопје, Р. Македонија

${ }^{2}$ Универзитетска клиника за ревматологија Скопје, Р. Македонија

Ревизијата во две фази претставува златен стандард во третманот на инфицирани ендопротези. Во трудот се обработени резултатите од 21 пациент со инфицирани ендопротези на колк третирани во две фази, со употреба на антибиотски спејсер, во период од 2009 до 2012 година.

Притоа, кај сите пациенти е применет единствен протокол на дијагноза и третман на инфекции и опфаќа предоперативна РТГ-слика, лабораториски иследувања (Се, ЦРП), како и аспирациона пункција со микробиолошко и биохемиско иследување на пунктатот. Оперативниот третман се состои со: земање примерок за ми- кробиолошка и патохистолошка дијагноза, вадење на имплантираната протеза, ексцизија на аваскуларно и некротично ткиво и поставување на антибиотски спејсер. Постоперативно, пациентите се третирани со и.в. апликација на антибиотик според антибиограм, во траење од две недели, а потоа со перорален третман во комбинација на два антибиотика, во зависност од антибиограмот во наредните од четири до шест недели. По смирување на локалниот наод и лабораториските резултати, кај пациентите е извршена ревизија со вадење на антибиотскиот спејсер и реимплантација на ендопротеза - ревизиска или примарна, во зависност од коскениот дефицит. Функционалноста на зглобот е оценувана според Haris Hip Score. Постоперативно пациентите се следат од 12 до 36 месеци.

Кај 20 пациенти е применета дефинитивна реимплантација, додека еден пациент е лекуван со ресекциска метода. Haris Hip Score предоперативно изнесува 45 , а постоперативно 80 .

Применетиот протокол на третманот кај инфицирани ендопротези е ефективен во ерадикацијата на инфекцијата и финалната реимплантација.

Клучни зборови: инфекција, колк, ендопротеза, спејcep. 